\title{
Do External and Internal Crises Affect Foreign Portfolio Inflows? The Case of China and India
}

\author{
Fayyaz Ahmad ${ }^{1}$, Muhammad Umar Draz ${ }^{2} \&$ Su-Chang Yang ${ }^{1}$ \\ ${ }^{1}$ School of Economics, Lanzhou University, Lanzhou City, Gansu Province, China \\ ${ }^{2}$ Department of Management and Humanities, Universiti Teknologi PETRONAS, Seri Iskandar, Perak, Malaysia \\ Correspondence: Muhammad Umar Draz, Department of Management and Humanities, Universiti Teknologi \\ PETRONAS, 32610 Bandar Seri Iskandar, Perak Darul Ridzuan, Malaysia. E-mail: umardraz2626@gmail.com
}

Received: April 16, 2016

doi:10.5539/ijef.v8n7p149

\begin{abstract}
This study examines the relationship between external and internal crisis (EIC) and Foreign Portfolio Investment (FPI) net inflows in China and India. We have applied Binary Choice Model taking the EIC as a dummy variable. GDP growth is an independent variable in our model that indicates the combined performance of economic sectors. The results suggest that EIC exert a significant impact on the FPI net inflows, but the nature of internal issues is different for both countries. We find a little association between GDP growth and net FPI inflows.
\end{abstract}

Keywords: China, economy, financial crisis, FPI, GDP, India

\section{Introduction}

Globalization and increasing financial integration have stimulated capital flows round the globe. Some well-known benefits of having integrated markets are: diversification of risk, exploration of new markets, exchange of information, and relatively high earning expectations among investors of various regions and markets. Capital flows eventually decrease a corporation's cost of capital and contribute to the economic growth. The benefits of long and short term capital flows are obvious, but the volatile nature of these flows gives credence to the notion that these flows are pro-crisis. The global financial crisis (GFC) of 2008 was the most challenging financial turmoil for both developed and developing countries.

Subprime crisis in the USA triggered this global financial crisis. The USA Government and Federal Reserve launched bailout packages of trillions of dollars that halted the contagion effect of turmoil for a short time period, but neither addressed nor solved the underlying causes of financial turbulence (Singhania \& Anchalia, 2013). In addition, the failure of Lehman Brothers, a major finance company, burst the credit bubble. Unavailability of credit and Liquidity crisis caused major slowdown to economic activities, and this set off a chain reaction from advanced to underdeveloped markets.

Economic activities of various sectors were affected at large scale during the aforementioned global financial crisis. Initial perception about the largest economies of emerging markets like Brazil, Russia, India and China (BRIC) was that they might escape from the worst effects of the crisis, but by the end of 2008, even Asian tycoons like India and China experienced a downturn in economic activities of different sectors and a slowdown of international capital flows as compared to the pre-crisis period (Enderwick, 2009). Among the BRIC nations, China and India are the most prominent recipient of foreign portfolio flows Garg and Dua (2014) discussed that during pre-crisis period Brazil, India and China are the recipient of 70 percent of total equity portfolio investment to all developing countries. Furthermore, massive reversal of portfolio flows during crisis resulted in deterioration of balance of payment. In addition, Indian economy faced the sharpest reversal in portfolio flows during recent subprime crisis.

Shamiri and Isa (2010) stated that FPI increased before the Asian financial crisis of 1997 and accounted for 40 per cent of the total capital flows in Asia. During the Asian financial crisis, a reversal occurred and sudden stops of capital flow paralyzed economy of most Asian countries. This financial crisis turned inflows into outflows; the reversal of short term capital flows was so severe that total outflows of short term portfolio reached 92 billion USD in 1998. Since last two decades, capital flows in Asia from the international markets gained momentum. This international intervention changed composition of capital flows and FPI and FDI have replaced direct bank 
lending.

In Asia, buoyant markets of India and China are attractive for foreign investors because of growth rates in comparison with other emerging economies. Though these markets are attractive, but at the same time vulnerable of economic turmoil. Motivated by large short term capital flows in both countries since last decade, our objective is to study ups and downs in short term net FPI inflows during crisis. Further, elaborate the impact of recent global financial turmoil and internal crisis on FPI with the help of Binary Choice model. In this study, internal crises refer to the internal issues which include policy changes, appreciation or depreciation of currency to control the inflationary effects and internal security and social issues. Whereas, external crisis indicate the major events leading to decisive social, economic or political changes in particular regional or round the globe. For our study period, the Asian financial crisis of 1997 and the Global financial crisis of 2008 are the dominant external crises.

The numerical data for crises is unavailable because measurement of crisis is not possible. To deal with this issue, we used external and internal crisis as dummy variable and data is in binary form. The presence of internal issue or external turmoil is denoted by 1 while, zero is in case of absence. To achieve this aim of understanding, the impact of financial crisis on FPI in Indian and Chinese economy, this paper is structured around seven main sections. After introduction, the following section discusses the existing literature on the impact of crises, especially about the emerging markets of Asia. The third section describes the history of major events during the last two decades in India and China. The fourth section explains FPI inflows' trend and major disparities, while the fifth section elaborates data and methodology. Section six consists of analysis and discussion, and the last section offers conclusion and recommendations.

\section{Literature Review}

The existing studies unanimously conclude that a financial turmoil stimulates the reallocations of both short and long term capital in various regions. The global financial crisis of 2008 was no exception and there were large reallocations of fund across regions and countries. Investors pulled out their funds from undergoing crisis countries and invest more in the relatively well performing portfolio during the recent crisis. The crisis affected certain equity markets and propagated to the European markets; because of propagations investors, particularly large institutions began to sell their equities which negatively influenced the value of portfolio of other participants. This simulation also negatively influenced the liquidity of European markets during the financial bubble. The literature also shows that the international investors adjust their portfolios during the crisis; investors from various countries adjust their funds at different degree for one destination and adjustments in the portfolio are considerable during the crisis. Reallocation of funds from international investors resulted in outflow and reversal of various types of capital flow.

Various components of capital flows pose a different degree of reversal. Capital flows are pro-cyclical, both inflows and outflows increase in expansion time and decrease during economic downfall. The dynamic pattern of capital flows is stronger than the past during the recent years. Gross capital flows are large and volatile in terms of size and volatility of net capital flows. During the crisis, gross capital flow collapse and retrenchments occur in every type of capital flow, but the effect is stronger during global financial crisis. Outflows of capital among various economies created waves of capital flow and there is a little association between capital controls and probability of surges and stops of foreign capital flows. Global factors, especially global risk, are significantly associated with extreme capital episodes. Contagion through trade, banking and geographical volatility is also associated with stops and retrenchment episodes (Sula \& Willett, 2009; Forbes \& Warnock, 2012; Raddatz \& Schmukler, 2012; Prorokowski, 2013; Galstyan \& Lane, 2013; Broner et al., 2013).

Behind all surges, stops and retrenchments, advanced countries play an important role in the crisis period. The economic slowdown of the developed nations causes economic turmoil in developing countries, because financial markets of underdeveloped countries show contagion response against the shocks transmitted from the developed markets. The economic prospects of G3 countries affected the movement of portfolio investment flows in the developing Asian countries and the recent financial turmoil caused a significant pullback of short-term capital flows. Portfolio investment and bank loans are more prone to crisis than direct investment, but financial fundamentals and institutions of Asian countries help to manage adverse effects.

It is a proven fact that advanced markets influence emerging markets. For less risk and relatively high profits, investors need to observe the financial shocks originated in the investing countries. It is necessary for international investors to pay attention to the US market volatility in order to earn profits from the Asian-Pacific markets. Due to large portfolio holdings of the US investors, these markets are vulnerable to shocks transmitted from source countries. Contrary to this, small markets can also cause volatility spillovers to advanced markets. 
Uncertainty in stock market of China might have had a significant effect on G5 countries and, because of irrational behavior of Chinese investors during the crisis; Chinese market entered a speculative bubble (Jongwanich, 2010; Shamiri \& Isa, 2010; Nishimura \& Men, 2010).

Although advanced markets are influential on developing and shocks from them are important for investors, but literature is evident that crisis disturbed the flow of capital in both markets. Advanced nations cannot isolate themselves from the consequences of a crisis. Central and Eastern European (CEE) equity market co-movements before, during and after major emerging market crises demonstrated a feedback effect and unidirectional causality. Furthermore, it confirmed a decrease in portfolio benefits during the crisis and an increase in the post-crisis period. Financial turbulence left its signs not only to advanced economies but also on developing economies in different regions. Global capital flows exhibited collapse and substantial shift during recent crisis push factors like; shocks from advanced countries, particularly from the USA, and macroeconomic policies indeed exerted a significant impact on capital flows from emerging and some advanced economies.

The rise in risk and global financial crisis event triggered a reallocation of funds from emerging to advanced economies for the safety of funds. Volatility in different regional markets influence capital flows in emerging markets because of intra-regional volatilities significant contagion effects exist among different types of capital flows of emerging economies. Such intra-regional effects are stronger for FPI in compassion with FDI, and these effects are stronger for net inflows as compared to gross inflows. Continuing integration in financial markets poses a trade-off for emerging economies. Associated with higher growth and other positive aspects, this situation also makes economies susceptible for global shocks and contagion effects. But comparing with the past, emerging economies did not fall more than advanced economies.

Vulnerability to external crisis slowed down the growth rate and also poverty reduction process. Arguing further, crisis transmitted multiple exogenous shocks to emerging economies, most important among them are the reversal of private capital flows and slump of trading activities. The intensity of two-way capital flows among advanced countries when compared with developing countries reveals the fact that occurrence of gross or net flows reversal is higher in the latter group. Recent turmoil was so severe that economies of the world, from Europe to Asia, could not avoid it (Patev et al., 2006; Fratzscher, 2012; Didier et al., 2012; Lee et al., 2013; Essers, 2013; Calderón \& Kubota, 2013).

During the ongoing European crisis, stock volatility returns in China and India turned negative while there was no significant impact on Japan and Hong Kong. During the slow-down phase, because of less or shaky confidence of investors and speculators, China and India experienced less trade than the post-crisis period. Due to the crisis and economic slowdown of the neighboring countries, short-term capital flows to Malaysia were penalized. Though effect was not strong, but capital controls influenced the compositions of capital flows. Although both FPI and FDI were affected during the domestic and global financial crisis, FDI reacted more strongly to the former and FPI responded more to the latter (Uctum \& Uctum, 2011; Singhania \& Anchalia, 2013; Amin \& Annamalah, 2013).

Though numerous studies have been conducted on financial crises, the impact of EIC on FPI in China and India is yet to be explored. Our study contributes to the literature by focusing on these two rival economies in Asia for a particular time span (i.e. 1997-2012). It examines the impact of the external crisis and internal issues on net FPI inflows. Moreover, our study explores and compares the different factors of economic disparity between two economies.

\section{China and India during the Last Two Decades}

Since the premiership of Deng Xiaoping, China started its economic reforms that helped to boost up the economic growth and took millions of people out of poverty. Initially, the Chinese government emphasized on the import of technology-based products as well as exported its local technology to accumulate foreign exchange reserves. During that time period, as elaborated by Hou (2011), earnings from foreign trade were very difficult due to the strict policies, but it led towards a new era of foreign capital flows, especially FDI. At present, China is the second largest recipient of FDI flows after the USA. The journey did not stop there; in 1994, China decided to adopt more liberal foreign trade policy and its government reduced the tariff on imports during 1996. Later on, China became a permanent member of the WTO in 2001. The Asian financial crisis of 1997 was a big blow for the emerging economies. During this crisis, China experienced a GDP slowdown and its GDP decreased from double to a single digit, but it did not turn negative (Draz, 2011).

The GFC was a big blow for many economies as well as for China. It hit different aspects of the Chinese economy; though exchange rate control and inconvertibility of currency shielded the Chinese economy from the external shocks, this protection proved to be insufficient during the GFC. This crisis increased unemployment, 
job insecurity and pay cuts in China (Voon \& Ma, 2014). The GFC hit various sectors of China including energy, exports and overall GDP. During this crisis, the Chinese exports fell down, consumption of energy also decreased and the GDP growth went down to 7.33\% (Yuan et al., 2010). The GFC damaged China's economy more than the Asian Financial Crisis; the short-term capital flows decreased significantly and FPI flows to China decreased by $39 \%$ in 2008 .

After gaining independence in 1947, India adopted socialism and the economic policies were strict and centralized. During the regime of Indira Gandhi (Prime Minister), efforts for a liberal economy were aborted. When Rajiv Gandhi was in power, opposition against liberalization was not strong as compared to previous reforms period. Although policies became reversed in a couple of years, the economy was much pro-liberal in his era (Sharma, 2011). An alarming situation occurred in the shape of serious budgetary and fiscal deficit along with a perilous balance of payment for the government in 1991. During this dangerous economic and fiscal chaos, foreign currency reserves, as stated by Dongre (2012), dropped down to 1 billion dollars with an annual inflation of $17 \%$.

Due to high fiscal deficit, foreign investors had lost confidence which resulted into an outflow of foreign capital and the Indian government went close to bankruptcy. As a result, India completely liberalized its economy to boost up its economic growth and attract the foreign investment from all over the world. The World Bank data shows that during Asian crisis Indian GDP reduced from 7.54\% to 4\%. During this period, not only GDP reduced significantly, but trade sector also experienced a slowdown. During the same period, Indian trade account deficit touched the alarming level amounting to 1.6 billion dollars (Nag \& Mukherjee, 2012). Since the last decade, the economy of India is flourishing and it is enjoying an average growth rate of $7 \%$.

At present, India is the second fastest-growing economy in Asia after China. The GFC was a massive blow for Indian economy during the recent decade which resulted in a significant decrease in net capital inflows and bank borrowings. During the first half of 2008-09, as Bajpai (2011) mentioned, net capital inflows declined by $63 \%$ as compared to last year; during the second half of the same period, net capital flows turned negative due to huge FPI outflows. The World Bank data shows a significant decline in Indian GDP during the crisis. The IMF record shows that during crisis total FPI inflows in India, by the end of 2008, declined by $44 \%$ in comparison with the last year.

\subsection{FPI Trend}

Emerging economies of Asia have been an attractive destination for the foreign investors during the last couple of decades. High growth rates and open policies of these markets increased their engagement in the global market. Participation of the big Asian economies in the world market altered the nature of competition among the economic powers. China, the world's second fastest-growing economy after the USA and the fastest-growing economy of Asia, attracted huge capital flows since 1997 from various parts of the world. India, the second fastest economy of Asia after China, has also become an increasingly important market for the global investors.

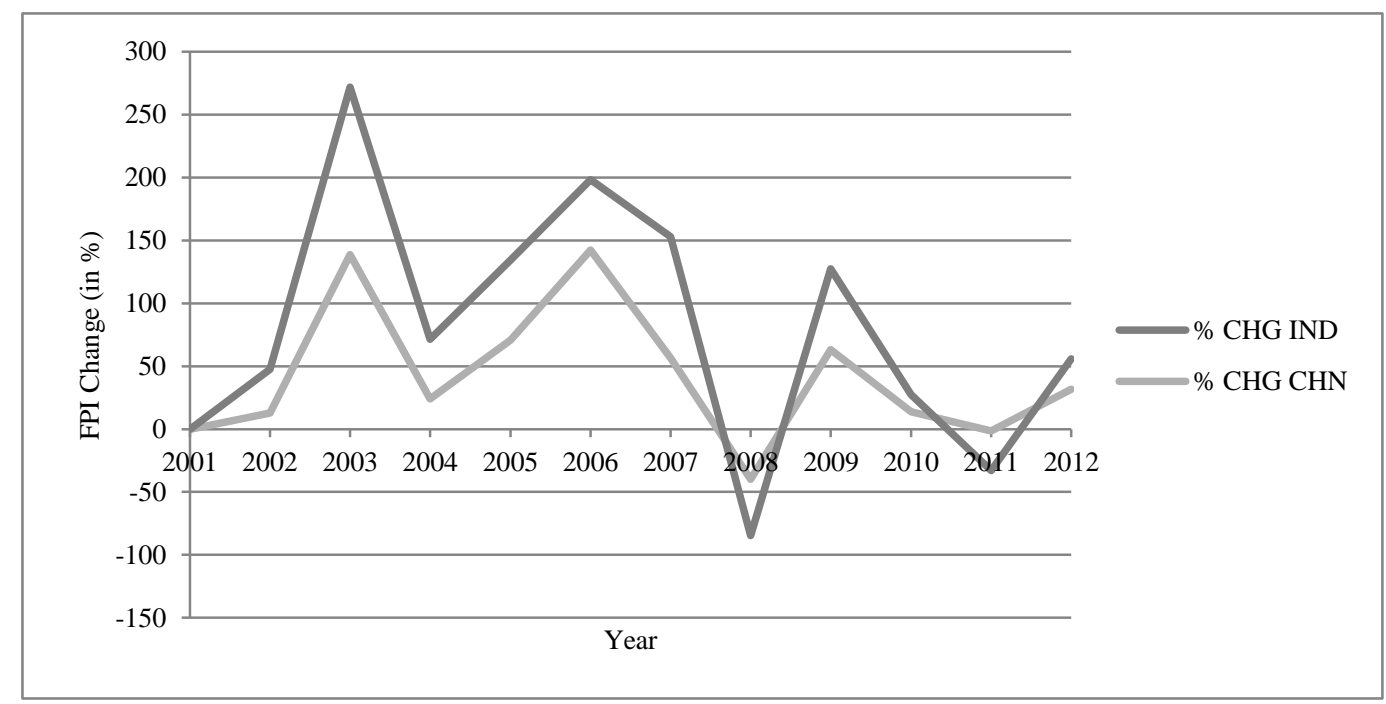

Figure 1. FPI trend in China and India 
The percentage changes in the portfolio inflows of India and China during the last decade are presented in Figure 1. Both countries attracted a significant amount of portfolio flows and overall trend of both countries is increasing in comparison with previous year. On average, the percentage increase is higher for China as compared to India and the main decrease can be observed during the GFC. A significant change has been observed in the behavior of portfolio capital flows in emerging economies, especially during the pre-crisis and post-crisis period of the GFC (Ahmed \& Zlate, 2014). At present, markets are integrated and spillovers of boom or recession affect economies around the globe.

Being prominent participants of the international market, both China and India could not isolate from the crisis. Both countries experienced a significant decrease in FPI during the GFC, but percentage decrease of FPI for both countries is not similar. The percentage decrease is larger for India as compared to China. The trend of FPI to China is smooth after recovery from the crisis, but a significant reversal occurred in FPI to India, which shows a larger inconsistency factor in the Indian market. Though both countries experienced large foreign capital flows, but a sudden reversal, especially in the Indian market, indicates various internal issues. In the next section, we will discuss internal issues of both countries.

\subsection{Major Factors behind Economic Disparity}

China and India are among the major economies of Asia and also rank among world's largest economies. Both countries attracted ample amount of foreign capital both in the shape of FPI and FDI. FPI trend of the last decade is more consistent for China as compared to India. This difference indicates various social, economic, infrastructural and political disparities between two countries that are elaborated as follows:

\subsubsection{GDP Growth}

Though both countries are enjoying a significant growth rate, but the World Bank data shows that China's GDP is more consistent than India's. Sudden and sharp changes occurred in the Indian economy either at the time of possible economic turmoil or during the boom period. This inconsistent pattern of economic growth reduces the confidence of foreign investors. Therefore, any financial turbulence can cause an ample amount of outflows from the stock markets.

\subsubsection{Political Stability}

Political stability is a key factor of concern while making an investment decision in any country. Politically volatile economy is always considered less attractive for any type of investment. New government introduces new policies, which may be unfavorable for foreign investors in terms of rules and regulations, investors' rights and tax. Reversal of policies is a common practice in the less-developed countries like India. On the other side, one party system is in practice in China and the Chinese Communist Party (CCP) is the ruling the country since its establishment; every successor government continues the previous policies and the chances for reversal are very less. This leads towards a greater confidence of investors. As a result, even during the crisis period, outflows are comparatively less for China as compared to India.

\subsubsection{Internal Security Issues}

Internal security is essential for a smooth working of all walks of life including the economy. Ethnicity, sectarianism and inter-provincial grievances in India and other emerging economies are common phenomena. Ethno-sectarian problems and independence movements, e.g. issues in Assam, Naxalite areas, and occupied Jammu and Kashmir, are some serious threat for the economic stability. Ethnic riots and terrorist attacks are also an important chapter of this tale and Gujarat riots in 2002, and Mumbai attacks in 2008 are the recent examples of this important issue. Accumulation of all these factors makes Indian economy vulnerable for a social and economic crisis. This unpredictable bubble creates a chaos for the foreign investors and huge outflows of funds occur in response to a little economic calamity. On the contrary, no big social issue that can destabilize the economy has emerged in China since the last decade. 


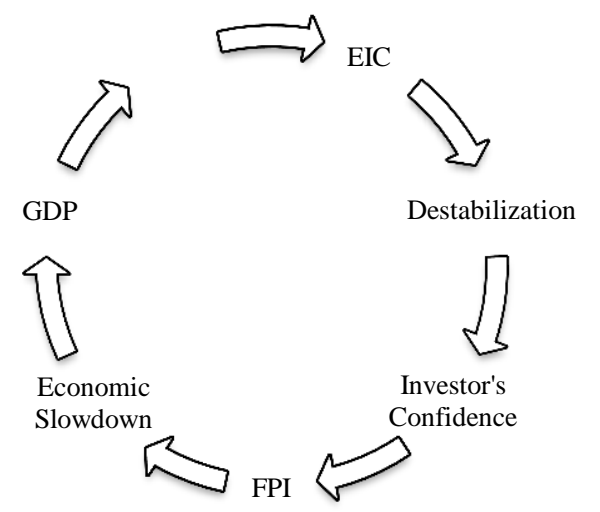

Figure 2. Impact of external and internal crises

\subsubsection{Cross Border Relationships}

Conflicts with the neighboring countries can cause a serious damage to all sectors of the economy. While investing in a country, the safety of funds, diversification of risk and expectations for return are considered to be the priorities of foreign investors. Unfriendly relations with the neighboring nations are a threat for economic stability and reduce the confidence of foreign investors. China has always tried to boost cooperation with its neighbors. Since the last decade, China has resolved its issues with the neighboring countries through serious diplomatic efforts. Major breakthroughs include an improvement in the Sino-Indian and Russian relationships by table talk. After years of effort, China is now enjoying the benefits of regional cooperation, but Indian relations with the surrounding countries are still a chaos. Since independence, India has fought several wars against Pakistan and both countries are still fighting a proxy war. Both countries are Nuclear Power and their relations are still alarming, which affect the economies of both countries significantly.

\subsubsection{Industrialization}

Despite its shortcomings, the industrial sector of China is growing with remarkable rates. Industrial transformation of China has moved the Chinese economy into a new orbit. Industrialization not only contributed towards GDP but also opened up opportunities for overseas investors. At present, many multinational companies have opened their franchises in China, which contributes a lot to attract foreign capital inflows. The World Bank reported that China's industrial sector contributed $46.56 \%$ to its GDP in 2011. On the other hand, the contribution of India's industrial sector was only $26.7 \%$ in the same year; it shows that India is still far behind China in terms of attracting physical capital from other countries. India relies on human capital and a significant portion of its GDP comes from the services sector.

\section{Methodology}

The study investigates the impact of internal and external issues on FPI of China and India. The net annual FPI inflows are analyzed for the period of 1997 to 2012. External issues refer to the financial crisis, and global financial crisis is the major external shock for both countries since last decade. Internal issues include policy and internal security issues during this period. FPI includes net FPI inflows and the relevant data is collected from the website of the World Bank. The data of GDP growth is also collected from World Bank website. GDP growth and inflation are taken as control variables because GDP indicates the performance of various sectors. Higher and comparatively consistent growth rates are helpful to strengthen the investors' confidence, which results into hot capital inflows in a country.

Binary Choice Model has been used for analysis in this paper because the data of financial crisis and internal issues is discrete so, Least Square method is not an appropriate measure for current data. Model is further divided into three types, i.e. Logit, Probit, and Extreme values. Binary models, as Hosmer \& Lemeshow (2000) stated, are applied to analyze such situations in which dependent variables can only have two possible outcomes i.e. (yes, no) or $(1,0)$, where 1 indicates the presence and 0 signifies the absence. Like other forms of regression, in binary models one or more predictors (independent) variables are used. Variables in our model are abbreviated as follows:
Foreign Portfolio Investment $=$ FPI
\{Dependent Variable\}
Gross Domestic Product $=$ GDP
\{Independent Variable $\}$ 
External and Internal Crisis = EIC

Inflation $=\mathrm{IFN}$

Whereas:

$\mathrm{EIC}=\left\{\begin{array}{l}1, \text { External \& Internal Crisis } \\ 0, \text { Otherwise }\end{array}\right\}$ and FPI $=\left\{\begin{array}{l}1, \text { Increase } \\ 0, \text { Otherwise }\end{array}\right\}$
\{Independent Variable

\{Independent Variable\}

Where EIC is a dummy variable applied to identify the presence or absence of a crisis. The hypotheses of our study are as follows:

$\mathrm{H}_{01}$ : There is no significant relationship between external and internal crisis and net FPI inflows of China / India

$\mathrm{H}_{11}$ : There is a significant relationship between external and internal crisis and net FPI inflows of China / India

\section{Results and Discussion}

This section represents various estimations, results and discussion. Descriptive summary of variables including dependent variable of China is presented in Table 1, which shows that IFN has the highest standard deviation; GDP indicates higher mean, kurtosis as well as higher value of JB. Summery statistics of China and India are shown in Table 1 below:

Table 1. Descriptive statistics

\begin{tabular}{clcccc}
\hline Country & Measures & IFN & EIC & FPI & GDP \\
\hline \multirow{5}{*}{ China } & Mean & 1.8998 & 0.3750 & 0.6250 & 9.6937 \\
& Median & 1.6442 & 0.0000 & 1.0000 & 9.3000 \\
& Std. Dev. & 2.3193 & 0.5000 & 0.5000 & 1.8031 \\
& Skewness & 0.2251 & 0.5163 & -0.5163 & 1.1178 \\
& Kurtosis & 1.8874 & 1.2666 & 1.2666 & 3.7118 \\
& Jarque-Bera & 0.9603 & 2.7140 & 2.7140 & 3.6760 \\
& & & & & 6.7594 \\
& Mean & 6.9298 & 0.3125 & 0.6875 & 7.0896 \\
& Median & 6.2577 & 0.0000 & 1.0000 & 2.4815 \\
& Std. Dev. & 3.1715 & 0.4787 & 0.4787 & -0.0494 \\
& Skewness & 0.6386 & 0.8090 & -0.8090 & 1.5089 \\
& Kurtosis & 2.1259 & 1.6545 & 1.6545 & 1.4886 \\
\hline
\end{tabular}

Source: Authors' analyses in Eviews.

In China's case, inflation has the highest SD, the skewness of FPI is negative, but kurtosis and JB are less than 3. We have applied the ADF and PP test to check stationary properties of data with the null hypothesis that data is non-stationary at $5 \%$ level of significance. The critical values provided by MacKinnon.

Table 2. Unit root analysis

\begin{tabular}{cccccc}
\hline \multirow{2}{*}{ Country } & \multirow{2}{*}{ Variables } & \multicolumn{2}{c}{ Augmented Dickey-Fuller (ADF) } & \multicolumn{2}{c}{ Phillips-Perron (PP) } \\
\cline { 3 - 5 } & & ADF test statistic & Critical value & PP test statistic & Critical value \\
\hline \multirow{6}{*}{ China } & FPI & -4.031129 & -3.081002 & -4.028423 & -3.081002 \\
& GDP & -3.517462 & -3.098896 & -3.519488 & -3.098896 \\
& EIC & -4.031129 & -3.081002 & -4.028423 & -3.081002 \\
& IFN & -7.699243 & -3.119910 & -9.206028 & -3.098896 \\
& & & & \\
India & FPI & -6.244998 & -3.081002 & -6.244998 & -3.081002 \\
& GDP & -4.364932 & -3.098896 & -5.631745 & -3.098896 \\
& EIC & -4.048036 & -3.098896 & -4.457145 & -3.081002 \\
& IFN & -5.679849 & -3.098896 & -5.288583 & -3.098896 \\
\hline
\end{tabular}

Source: Authors' analyses in Eviews. 
Results for both countries are presented in Table 2 confirming that all variables are stationary at $5 \%$ level of significance. Therefore, we reject our null hypothesis.

Correlation matrix for both countries is shown in Table 3. The values of correlation are significantly small, which indicates that there is no multicollinearity among the variables.

Table 3. Correlation analysis

\begin{tabular}{cccccc}
\hline Country & Variables & INF & GDP & FPI & EIC \\
\hline \multirow{6}{*}{ China } & INF & 1.000000 & & & \\
& GDP & 0.449633 & 1.000000 & & \\
& FPI & -0.178381 & 0.100750 & 1.000000 & \\
\multirow{4}{*}{ India } & EIC & 0.241545 & 0.121085 & -0.733333 & 1.000000 \\
& & & & & \\
& INF & 1.000000 & & & \\
& GDP & 0.069664 & 1.000000 & & \\
& FPI & -0.277895 & 0.236824 & 1.000000 & \\
& EIC & 0.213097 & -0.281769 & -0.709090 & 1.0000000 \\
\hline
\end{tabular}

Source: Authors' analyses in Eviews.

The results of Binary Choice Model demonstrate that, with 5\% level of significance (i.e. $\alpha=0.05$ ), a significant relationship exists between net FPI inflows and the external and internal crisis of China and India. All methods (i.e. Probit, Logit and Extreme Values) indicate a significant impact of EIC on FPI net inflows. Hence, we reject our null hypothesis $\left(\mathrm{H}_{01}\right)$ that there is no significant relationship between EIC and FPI net inflows of China and India. Moreover, the relationship of GDP and FPI net inflows varies for both countries; all methods of our model indicate an insignificant relationship between India's GDP and FPI net inflows, however, a significant but weak relationship exists between China's GDP and FPI net inflows.

Table 4. Binary choice model - China

\begin{tabular}{cccccc}
\hline Method & Variables & Coefficient & Std. Error & z-Statistic & Prob. \\
\hline \multirow{3}{*}{ Binary - Probit } & EIC & -2.659179 & 1.080830 & -2.460311 & 0.0139 \\
& GDP & 0.379541 & 0.324684 & 1.168954 & 0.2424 \\
& IFN & -0.161597 & 0.289248 & -0.558681 & 0.5764 \\
& & & & & \\
Binary - Logit & EIC & -4.421092 & 1.965038 & -2.249876 & 0.0245 \\
& GDP & 0.614971 & 0.565604 & 1.087284 & 0.2769 \\
Binary - Extreme & IFN & -0.296457 & 0.527733 & -0.561756 & 0.5743 \\
Values & EIC & -3.214372 & 1.374338 & -2.338852 & 0.0193 \\
& GDP & 0.439070 & 0.417040 & 1.052825 & 0.2924 \\
\hline
\end{tabular}

Source: Authors' analyses in Eviews.

Table 5. Binary choice model - India

\begin{tabular}{cccccc}
\hline Method & Variables & Coefficient & Std. Error & z-Statistic & Prob. \\
\hline \multirow{3}{*}{ Binary - Probit } & EIC & -2.099687 & 0.897023 & -2.340727 & 0.0192 \\
& GDP & 0.028527 & 0.177988 & 0.160276 & 0.8727 \\
Binary - Logit & IFN & -0.102899 & 0.146975 & -0.700111 & 0.4839 \\
& EIC & -3.529241 & 1.618636 & -2.180379 & 0.0292 \\
Binary - Extreme & GDP & 0.102292 & 0.324844 & 0.314897 & 0.7528 \\
Values & IFN & -0.197235 & 0.270972 & -0.727879 & 0.4667 \\
& EIC & -2.859514 & 1.251741 & -2.284429 & 0.0223 \\
& GDP & 0.162272 & 0.252303 & 0.643163 & 0.5201 \\
& IFN & -0.174854 & 0.214922 & -0.813568 & 0.4159 \\
\hline
\end{tabular}

Source: Authors' analyses in Eviews. 
Our results are theoretically reliable. As compared to India, China experienced remarkable growth rates, less fluctuation in growth, better governance, improved infrastructure and stable political and internal security situation. Therefore, China attracted ample amount of foreign capital by the virtue of its development in various sectors.

\section{Conclusion}

This study investigates the relationship between external and internal crisis (EIC) and net inflows of FPI for China and India. We have used GDP and inflation as control variables and applied Binary Choice Model taking the EIC as a dummy variable for both countries. The statistical results suggest that net FPI inflows are significantly influenced by EIC. Regardless of the impact, the nature of internal issues is different for both countries. Meanwhile, the relationship between GDP and net FPI inflows is not strong. Our study reveals that China's internal issues, i.e. appreciation of the currency, pegging, and un-pegging with the USD, are mostly related to its policy measures because there is a tradeoff between inflation rate and the surge of inflows into the country. Therefore, policy makers can look into the timing and impact of certain policy measures on inflation control and its relative impact on FPI inflows. Moreover, China needs to sustain its growth rate and carefully design the competitive policies to attract the foreign investors.

On the contrary, we found that India is undergoing serious internal security, societal and regional problems. In addition, its GDP is not as consistent as China's and investors react strongly against all these issues. Therefore, India should pay attention to remove ethnic, social and economic inequalities in order to reduce the internal security threats. Furthermore, serious efforts are required to maintain friendly relations within the neighboring countries, which will be useful in enhancing the investors' confidence and sustaining the growth rate.

\section{References}

Ahmed, S., \& Zlate, A. (2014). Capital Flows to Emerging Market Economies: A Brave new World? Journal of International Money and Finance, 1-28. http://dx.doi.org/10.1016/j.jimonfin.2014.05.015

Amin, F., \& Annamalah, S. (2013). An Evaluation of Malaysian Capital Controls. Journal of Economic Studies, 549-571. http://dx.doi.org/10.1108/JES-08-2011-0099

Bajpai, N. (2011). Global Financial Crisis, its Impact on India and the Policy Response. Mumbai: Columbia Global Centers|South Asia, Columbia University.

Broner, B., Didier, T., Erce, A., \& Schmukler, S. (2013). Gross Capital Flows: Dynamics and Crises. Journal of Monetary Economics, 113-133. http://dx.doi.org/10.1016/j.jmoneco.2012.12.004

Calderón, C., \& Kubota, M. (2013). Sudden Stops: Are Global and Local Investors Alike? Journal of International Economics, 122-142. http://dx.doi.org/10.1016/j.jinteco.2012.05.010

Didier, T., Hevia, C., \& Schmukler, S. (2012). How Resilient and Counter Cyclical Were Emerging Economies During the Global Financial Crisis? Journal of International Money and Finance, 2052-2077. http://dx.doi.org/10.1016/j.jimonfin.2012.05.007

Dongre, A. P. (2012). Policy Changes in the Wake of Globalization and its Impact on Indian Industries. Journal of Policy Modeling, 476-496. http://dx.doi.org/10.1016/j.jpolmod.2011.10.004

Draz, M. U. (2011). Impact of Financial Crises on Pakistan and China: A Comparative Study of six Decades. Journal of Global Business and Economics, 174-186.

Enderwick, P. (2009). Responding to Global Crisis: The Contribution of Emerging Markets to Strategic $\begin{array}{lllll}\text { Adaptation. International Journal of } & \text { Emerging }\end{array}$ http://dx.doi.org/10.1108/17468800910991250

Essers, D. (2013). Developing Country Vulnerability in Light of The Global Financial Crisis: Shock Therapy? Review of Development Finance, 61-83. http://dx.doi.org/10.1016/j.rdf.2013.02.001

Forbes, K. J., \& Warnock, F. E. (2012). Capital Flow Waves: Surges, Stops, Flight, And Retrenchment. Journal of International Economics, 235-251. http://dx.doi.org/10.1016/j.jinteco.2012.03.006

Fratzscher, M. (2012). Capital Flows, Push Versus Pull Factors and the Global Financial Crisis. Journal of International Economics, 341-356. http://dx.doi.org/10.1016/j.jinteco.2012.05.003

Galstyan, V., \& Lane, P. R. (2013). Bilateral Portfolio Dynamics During The Global Financial Crisis. European Economic Review, 63-74. http://dx.doi.org/10.1016/j.euroecorev.2012.10.002

Garg, R., \& Dua, P. (2014). Foreign Portfolio Investment Flows to India. World Development, 16-28. 
http://dx.doi.org/10.1016/j.worlddev.2014.01.030

Hosmer, D. W., \& Lemeshow, S. (2000). Applied Logistic Regression. New York: John Wiley \& Sons, Inc.

Hou, J. W. (2011). Economic Reform of China: Cause and Effects. The Social Science Journal, 419-434. http://dx.doi.org/10.1016/j.soscij.2011.06.009

Jongwanich, J. (2010). Capital Mobility in Developing Asia How Does It Respond to the Financial Crises? ASEAN Economic Bulletin, 27-54. http://dx.doi.org/10.1355/ac27-1c

Lee, H. H., Park, C. Y., \& Byun, H. S. (2013). Do Contagion Effects Exist in Capital Flow Volatility? Journal of The Japanese and International Economies, 76-95. http://dx.doi.org/10.1016/j.jjie.2013.10.002

Nag, B., \& Mukherjee, J. (2012). The Sustainability of Trade Deficits in the Presence of Endogenous Structural Breaks: Evidence From the Indian Economy. Journal of Asian Economics, 519-526. http://dx.doi.org/10.1016/j.asieco.2012.05.003

Nishimura, Y., \& Men, M. (2010). The Paradox of China's International Stock Market Co-movement. Evidence From Volatility Spillover Effects Between China and G5 Stock Markets. Journal of Chinese Economic and Foreign Trade Studies, 235-253. http://dx.doi.org/10.1108/17544401011084316

Patev, P., Kanaryan, N., \& Lyroudi, K. (2006). Stock Market Crises and Portfolio Diversification in Central and Eastern Europe. Managerial Finance, 415-432. http://dx.doi.org/10.1108/03074350610657436

Prorokowski, L. (2013). Lessons From Financial Crisis Contagion Simulation in Europe. Studies in Economics and Finance, 159-188. http://dx.doi.org/10.1108/10867371311325453

Raddatz, C., \& Schmukler, S. (2012). On the International Transmission of Shocks: Micro-Evidence From $\begin{array}{llll}\text { Mutual Fund Portfolios. Journal of International Economics, 357-374. } & \text { of }\end{array}$ http://dx.doi.org/10.1016/j.jinteco.2012.05.006

Shamiri, A., \& Isa, Z. (2010). Volatility Transmission: what do Asia-Pacific Markets Expect? Studies in Economics and Finance, 299-313. http://dx.doi.org/10.1108/10867371011085147

Sharma, C. K. (2011). A Discursive Dominance Theory of Economic Reform Sustainability: The Case of India. India Review, 126-184. http://mpra.ub.uni-muenchen.de/31001/

Singhania, M., \& Anchalia, J. (2013). Volatility in Asian Stock Markets and Global Financial Crisis. Journal of Advances in Management Research, 333-351. http://dx.doi.org/10.1108/JAMR-01-2013-0010

Sula, O., \& Willett, T. (2009). The Reversibility of Different Types of Capital Flows to Emerging Markets. Emerging Markets Review, 296-310. http://dx.doi.org/10.1016/j.ememar.2009.08.001

Uctum, M., \& Uctum, R. (2011). Crises, portfolio flows, and foreign direct investment: An application to Turkey. Economic Systems, 462-480. http://dx.doi.org/10.1016/j.ecosys.2010.10.005

Voon, J. P., \& Ma, Y. C. (2014). Global Financial Crisis and Perceptions of Job Insecurity: The China Case. Journal of Behavioral and Experimental Economics, 138-148. http://dx.doi.org/10.1016/j.socec.2014.09.002

Yuan, C., Liu, S., \& Xie, N. (2010). The Impact on Chinese Economic Growth and Energy Consumption of the Global Financial Crisis: An Input-Output Analysis. Energy, 1805-1812. http://dx.doi.org/10.1016/j.energy.2009.12.035

\section{Copyrights}

Copyright for this article is retained by the author(s), with first publication rights granted to the journal.

This is an open-access article distributed under the terms and conditions of the Creative Commons Attribution license (http://creativecommons.org/licenses/by/3.0/). 